\title{
EDITORIAL
}

\section{Can health economics help us understand our strange public health care system?}

\author{
ULF-G. GERDTHAM
}

This new Nordic journal publishes empirical and theoretical research in the field of health economics and in all of its constituting areas, such as measurement and valuation of health, the role of health on income, lifestyle and employment, the factors on demand and supply of health care, the functioning of the market for health care services, social and long-term care, the outcome of whole health systems with reference to overall goals of fairness and efficiency, economic evaluations of specific interventions of health, and priority setting. Although health economics is a young sub-discipline of economics, it has contributed by research in each of the above areas and also to the development of economic theory and methods. Health economics has also become a research discipline to be reckoned with, not only by economic researchers themselves but also by medicalrelated researchers, health policy makers, and medical technology industries. Nonetheless, many research and policy relevant key issues remain unsolved. The focus of this journal is broad and all contributions of high-quality in the areas of health economics by researchers both within and outside the Nordic countries will be considered for publication, solely on the basis of their scientific value.

Given the wide range of issues that are addressed in modern health economics, a Nordic journal may hopefully stimulate research on publicly-oriented health-care systems and may counter-balance the strong dominance of research on market-oriented health-care systems. For example, numerous studies have shown that doctors change their behavior when financial incentives change (overviews in McGuire $(2000,2011)$ ) and also that doctors sometimes manipulate the patient's demand (Gruber and Owings, 1996). Even though health economics research occasionally have been carried out on publicly employed doctors (e.g. Iversen and Ma 2009, Tjerbo 2010), evidence is relatively scant. Much remains to be learned about the public-private mix in health care and the incentives in the doctor-patient relationship in public health-care systems. Our current understanding of the providers of public health-care is largely restricted to doctors' working under similar payment schemes as used in market systems, i.e. mainly capitation and fee-forservice (Gravelle et al. 2003; Iversen and Siciliani, 2011). Furthermore, there is not much consensus yet in the literature on how one should model public hospitals (or private notfor-profit hospitals) and behavior of hospital-based doctors which are reimbursed by a fixed salary. More research is required on incentives beyond financial incentives, e.g. status-related factors and social interaction, and further how economic factors such as waiting lists and budget deficits affect behavior of suppliers and patients. These issues are of major importance for the understanding of public health care and the public-private choices in health care, critical for any health-care policy and reform.

Thus, additional research on health-care providers in public settings are important in order to progress understanding about the potential for increased efficiency in the production of health care and are also a key input into an analysis of the distribution of health and health care across socioeconomic groups and regions. Further the new journal may hopefully also stimulate research collaboration between researchers in the Nordic countries in order to enlarge understanding of our Nordic-specific public health care 
system. It is well known that the Nordic systems exhibit several similarities. They are based on similar basic principles of universalism, equality of access and as a result of these goals, the health-care system rely largely on public ownership and control and limited use of market-based incentives such as choice or competition, and rationing in the form of waiting lists. Out of pocket payment plays a minor role and is also accompanied by safety nets in the form of caps on expenditure. The health care in the Nordic countries are also provided within a decentralized public model, where local governments (municipals or county councils) are responsible for providing necessary health care to their population, though financing of the health care providers stem from a mix of local or central taxes which varies largely across the countries. The proportion of health-care spending, as a proportion of GDP are somewhat higher among the Nordic countries than the OECD average, but there are relatively large differences in per capita spending partly due to the higher GDP in Norway. A fact is also that the health-care systems in the Nordic countries have changed over the past 20 years without changing the underlying objectives (Magnusson 2009, Iversen 2011). As most western countries, the Nordic countries have faced an increased demand for health care as a result of the continuous progress of new medical technologies, changing demographics, and increasing expectations in the populations. Since the willingness to expand the health-care resources through increased taxes and mandatory insurances has been limited, the health-care sectors have increasingly been required to take into account a strict budget constraint. The standard cure for this economic problem has been to increase privatization and competition in the public health care in all the Nordic countries. This stratagem has become an intensely debated issue in recent times in all these countries. The similarities in the Nordic countries in the goals, overall systems and trends, combined with the existing differences within countries and across countries in the health-care systems (Iversen 2011) and the relatively advantageous access to high-quality registry and survey data with the possibility of linking data, makes it particularly interesting to provide forward-looking research on our public systems which should also be of interest outside the Nordic countries.

The meager understanding of our public systems becomes particularly apparent when the system faces reforms and it turns out that expected outcomes are uncertain. One recent example of reform from Sweden is the construction of quasi-markets in primary care in arrangement of a choice of care model. Since January $1^{\text {st }} 2010$, all Swedish county councils have implemented unrestricted choice for the population with money following registration with primary care provider and freedom of establishment for private providers that fulfill requirements as determined by the county councils (see Law 2008:962 choice of care model ). The aim of the reform is, inter alia, to provide more patient choice, to promote diversity and bring the patient's needs at the center of the health care system (Konkurrensverket 2010, Socialstyrelsen 2010). The county councils in Sweden have freedom to shape their own model of choice of care (see prop. 2008/09: 74) and have different reimbursement principles, which may lead to different outcomes on the quality of care (Anell and Paulsson 2010). Reimbursement of the care unit in all choice of care models are in the form of a fixed (but risk-adjusted) reimbursement per listed patient, i.e. capitation, and in the form of variable reimbursement, such as a fee per visit. The choice of care model aimed to create competition but it is currently unclear whether the choice of care models conditions is sufficient to meet the intended goal. Furthermore, it is unclear how health care producers' behavior is affected by increased economic incentives? A central part of the Swedish debate is much about economic incentives that makes the quality suffer. In Sweden, SNS Report "On the implications of competition" (Hartman 2011) further intensified the debate whether competition and privatization of public services, including health care, has led to societal benefits or not. 
This new and Nordic journal welcomes all kinds of contributions to health economics in all areas by researchers inside and outside the Nordic countries. My personal hope though, is that the journal will publish many high-quality contributions that shed light on and improve our understanding of the functioning of public systems of hierarchical hospital organizations and of doctors, and other health personnel, as salaried employees.

Chief Editor

Ulf-G. Gerdtham

\section{References}

Anell A and Paulsson G (2010):"Valfrihet och konkurrens i primärvården", i Anell A and Gerdtham U-G (red.), SNS Välfärdsrapport 2010 Vårdens utmaningar, SNS Förlag, 176-206.

Gravelle H, Sutton M, Morris S, Windmeijer F, Leyland A and Dibben C och Muirhead M (2003): "Modelling supply and demand influences on the use of health care: implications for deriving a needs-based capitation formula", Health Economics, 12, 985-1004.

Gruber, J. and Owings, M. (1996), Physician financial incentives and Cesarean section delivery, RAND Journal of Economics 27, 99-123.

Hartman, Laura (2011) (red): Konkurrensens konsekvenser. Vad händer med svensk välfärd? Stockholm: SNS

Iversen T. and Ma C A (2009): "Market conditions and general practitioners' referrals", working paper 2009:8, HERO, Oslo Universitet.

Iversen,T. (2011). Vägval i vården - en ESO-rapport om skillnader och likheter i Norden. Rapport till Expertgruppen för studier i offentlig ekonomi 2011:7. Finansdepartementet. Elanders Sverige AB, Stockholm.

Iversen, T. and Siciliani, L. (2011). Non-price rationing and waiting times. In In Glied, S., Smith, P.C. (eds.), The Oxford Handbook of Health Economics, Oxford University Press.

Konkurrensverket (2010): “Uppföljning av vårdval i primärvården. Valfrihet, mångfald och etableringsförutsättningar”, rapport 2010:3.

Magnusson, J. (2009). The Scandinavian Healthcare System. Medical Solutions. Essay Series: Healthcare Systems - Scandinavia.

McGuire, T.G. (2000) "Physician Agency". In Culyer, A.J. and Newhouse, J.P. (Eds.) Handbook of Health Economics, vol 1A: 461-536, Elsevier.

McGiure, T.G. (2011). Physician agency and payment for primary medical care. In Glied, S., Smith, P.C. (eds.), The Oxford Handbook of Health Economics, Oxford University Press.

Regeringens proposition 2008/09:74, Vårdval i primärvården.

Socialstyrelsen (2010): "Införandet av vårdval i primärvården. Slutredovisning”. Stockholm.

Tjerbo T (2010): "Does competition among general practitioners increase or decrease the consumption of specialist health care?" Health Economics, Policy and Law, 5, 53-70. 